Open Access

\title{
Triacylglycerol composition, physico- chemical characteristics and oxidative stability of interesterified canola oil and fully hydrogenated cottonseed oil blends
}

\author{
Muhammad Imran $^{1 *}$ and Muhammad Nadeem²
}

\begin{abstract}
Background: Partial hydrogenation process is used worldwide to produce shortening, baking, and pastry margarines for food applications. However, demand for such products is decreased during last decade due to their possible links to consumer health and disease. This has raised the need to replace hydrogenation with alternative acceptable interesterification process which has advantage in context of modifying the physico-chemical properties of edible fat-based products. Therefore, the main mandate of research was the development of functional fat through chemical interesterification of canola oil $(\mathrm{CaO})$ and fully hydrogenated cottonseed oil (FHCSO) mixtures.

Methods: Blends were prepared in the proportions of 75:25 $\left(T_{1}\right), 50: 50\left(T_{2}\right)$ and 25:75 $\left(T_{3}\right)$ of CaO:FHCSO (W/W). Interesterification was performed using sodium methoxide $(0.2 \%)$ as catalyst at $120{ }^{\circ} \mathrm{C}$, under reduced pressure and constant agitation for 60 minutes. The non-interesterified and interesterified CaO:FHCSO blends were evaluated for triacylglycerol (TAG) composition, physico-chemical characteristics, oxidative stability and consumer acceptability at 0,30 and 60 days of storage interval.

Results: The oleic acid ( $58.3 \pm 0.6 \%)$ was predominantly present in $\mathrm{CaO}$ while the contents of stearic acid $(72 \pm 0.8 \%)$ were significantly higher in FHCSO. Maximum trisaturated $\left(S_{3}\right)$ contents $(63.9 \pm 0.5 \%)$ were found in $T_{3}$ while monounsaturated $\left(S_{2} U\right)$, diunsaturated $\left(U_{2} S\right)$ and triunsaturated $\left(U_{3}\right)$ contents were quite low in $T_{2}$ and $T_{3}$ before interesterification. A marked reduction in $S_{3}$ and $U_{3}$ contents with concomitant increase in $S_{2} U$ and $\mathrm{U}_{2} \mathrm{~S}$ contents was observed for all CaO:FHCSO blends on interesterification. During storage, the changes in $S_{3}, S_{2} U$ and $U_{2} S$ contents were not found significant ( $p \geq 0.05$ ). However, maximum decrease $13 \%, 7.5$ and $5.6 \%$ in $U_{3}$ contents for $T_{1}, T_{2}$ and $T_{3}$ was noted after 60 -days of interesterification, respectively. The Lovibond color $R$, melting point, refractive index, specific gravity, peroxide and free fatty acids values of CaO:FHCSO blends decreased after interesterification and increased within the permissible limits during storage ( $p \geq 0.05)$. The CaO:FHCSO blends maintained their sensory acceptability before and after interesterification which decreased significantly as storage length increased from days 30 to 60-days. Most important was the $50 \% \mathrm{CaO}: 50 \% \mathrm{FHCSO}$ blend $\left(\mathrm{T}_{2}\right)$ which possessed the desirable TAG profile, physico-chemical and sensory characteristics coming from $T_{1}$ and $T_{3}$.
\end{abstract}

Conclusions: The present study concludes that functional lipids with desirable characteristics can be developed through interesterification of $50 \% \mathrm{CaO}: 50 \%$ FHCSO blend and should be explored as ingredient for the production of various healthier products for discerning consumers.

Keywords: Canola oil, Hydrogenated cottonseed oil, Interesterification, Fat-based products, TAG, Storage stability, Discerning consumers

\footnotetext{
* Correspondence: imran@gcuf.edu.pk

${ }^{1}$ Institute of Home and Food Sciences, Faculty of Science and Technology,

Government College University, Faisalabad, Pakistan

Full list of author information is available at the end of the article
} 


\section{Background}

Lipids constitute an important component of human diet and have many important functions in the human health and disease. Generally, they are found in every cell membrane of biological system and serve as a source of essential fatty acids such as linoleic acid and $\alpha$-linolenic acid, vehicles for fat-soluble vitamins (A, D, E and K), and provision of energy. The consumption of omega-3 fatty acids in foods tends to block the development of atherosclerosis, reduces the number of subsequent heart attacks, interferes with abnormal clotting of the blood, and coronary thrombosis. They may be active also against certain forms of cancer, immunological diseases, hypertension and hyperlipidemic conditions [1]. Of particular importance to nutrition and culinary specialists is that lipids provide satiety through their aroma, taste and texture. When fats and oils are eliminated in cooking and baking, the final products can be tasteless and unsatisfying $[2,3]$. The scientific community agrees that fats and oils enhance the texture and palatability of foods through their wide range of melting and crystallization properties. Interesterification, hydrogenation and fractionation are three processes available to food manufactures to tailor the physical, functional and chemical properties of food lipids. Approximately, $10 \%$ of all edible oils and fats in the world are fractionated or interesterified while onethird is fully hydrogenated $[4,5]$.

Partial hydrogenation is a chemical process leading to the saturation of double bonds to harden fats for use as margarines and shortening base stocks. Unfortunately, it has been determined that partial hydrogenation of vegetable oils is the main source of trans fatty acids in fried or processed foods. High intake of trans fatty acids as compared to saturated fatty acids increase the level of LDL-cholesterol, total cholesterol and triglycerides in the bloodstream which lead toward high risk of atherosclerosis and coronary heart disease [6,7]. This has raised the need to replace partially hydrogenated fats with alternative acceptable fats. Consequently, industries involved in food processing are looking for alternative to partial hydrogenation for making shortening and hard fats $[8,9]$. Chemical interesterification is of major importance to edible oil industry for the preparation of plastic fat with low trans isomer contents or even with the absence of these compounds and providing the functional properties necessary to meet the challenges of today's food industry [10]. Chemical interesterification is a relatively straightforward reaction which consist of catalyst activation, ester bond cleavage and fatty acid interchange steps. Interesterification process causes fatty acids redistribution within and among triacylglycerol molecules which can lead to substantial changes in lipid functionality. Commercially, the interesterification process is regularly used in processing fully hydrogenated vegetable oil and liquid oil blends to produce a variety of margarines, frying oils and confectionery fats [11]. Important factors that determine the application of such interesterified fats include fatty acids composition, physico-chemical characteristics, oxidative stability and consumer acceptability [12]. The situation demands to explore the potential of chemical interesterification process for development of modified functional fat with desirable composition for discerning consumers using commercially available vegetable oils. $\mathrm{CaO}$ stands as interesting substrate with comprehensive unsaturated fatty acids composition and free of trans fatty acids while FHCSO shows desirable characteristics for the production of interesterified fat base with considerable saturated fatty acids concentration. The main objectives of study were to change the overall physical, chemical and sensory profile of $\mathrm{CaO}$ and FHCSO blends by chemical interesterification process.

\section{Methods}

\section{Raw materials}

The seeds of canola were procured from Oilseeds Research Institute, Faisalabad, Pakistan. The unprocessed seeds were cleaned to remove any debris or field dirt and any other extraneous matters. $\mathrm{CaO}$, obtained by pressing the seeds in mini oil presser (china made; capacity $2-3 \mathrm{~kg} / \mathrm{h}$ ), was bleached by heating it to $110{ }^{\circ} \mathrm{C}$, mixing with clay (bentonite) for $30 \mathrm{~min}$ and filtered. Refined and deodorized $\mathrm{CaO}$ was cooled and stored in Tin cans of $1-\mathrm{kg}$ capacity (0.20 mm sheet thickness with flange of $2-\mathrm{mm})$ at $5 \pm 1{ }^{\circ} \mathrm{C}$. Refined, bleached and deodorized FHCSO was obtained from United Industries, Ltd. Kashmir Road, Faisalabad while sodium methoxide (Merck) was purchased from a scientific supplier of Lahore, Pakistan.

\section{Blend preparation}

FHCSO was supplemented into Cao at three different levels i.e. $\mathrm{T}_{1}$ (75 \% CaO and $25 \%$ FHCSO), $\mathrm{T}_{2}(50 \%$ $\mathrm{CaO}$ and $50 \%$ FHCSO $)$ and $\mathrm{T}_{3}(25 \% \mathrm{CaO}$ and $75 \%$ FHCSO). Each of the prepared blends was placed into a round bottom flask $(1000 \mathrm{~mL})$. For an optimum interesterification reaction, the oil portion $(500 \mathrm{~mL})$ was neutralized and oven dried at $60{ }^{\circ} \mathrm{C}$ to ensure a good result for catalyst consumption.

\section{Chemical interesterification process}

Chemical interesterification of treatments was carried out according to the method of Grimaldi et al. [13] with some modifications. Sodium methoxide was used as catalyst $(0.2 \%)$ for chemical interesterification. When reaction temperature of sample reached the $120{ }^{\circ} \mathrm{C}$, sodium methoxide was added under reduced pressure and constant agitation for $60 \mathrm{~min}$. The temperature was then decreased to $90{ }^{\circ} \mathrm{C}$. To end the reaction with 
distinctive dark brown color, an excess of citric acid (20\%) was added to neutralize the catalyst. The excess of citric acid and sodium methoxide was removed with warm water washes and the samples were vacuum-dried. Residual water was removed with an excess of anhydrous sodium sulfate (15\%), followed by filtration through Whatman \# 2 filter paper and oven dried at $60{ }^{\circ} \mathrm{C}$.

\section{Triacylglycerol composition}

The triacylglycerol composition of experimental samples was determined by the method Ce 1f-96 given in AOCS [14]. The oil sample $(50 \mu \mathrm{L})$ was methyated in the presence of $4 \mathrm{~mL} \mathrm{KOH}(1 \mathrm{M})$ at room temperature for $1 \mathrm{~h}$ in order to convert fatty acids into their respective methyl esters. The resultant fatty acid methyl esters (FAMEs) were extracted with GC grade $\mathrm{n}$-hexane and analyzed by Gas Chromatograph (Varian 3900) apparatus equipped with an auto sampler, flame-ionization detector (FID) and supelco wax column (30 $\mathrm{m} \times 0.25 \mu \mathrm{m}$ film coating). The samples $(1 \mu \mathrm{L})$ were injected with Helium $(1 \mathrm{~mL} / \mathrm{min})$ as a carrier gas onto the column, which was programmed for operating conditions such as column oven temperature $160{ }^{\circ} \mathrm{C} @ 0$ min with subsequent increase of $3{ }^{\circ} \mathrm{C} / \mathrm{min}$ until $180^{\circ} \mathrm{C}$. The column oven temperature was increased from $180{ }^{\circ} \mathrm{C}$ to $220{ }^{\circ} \mathrm{C} @ 1{ }^{\circ} \mathrm{C} / \mathrm{min}$ and was held for $7.5 \mathrm{~min}$ at $220{ }^{\circ} \mathrm{C}$. Split ratio was $50 \%$ with injector $240{ }^{\circ} \mathrm{C}$ and detector $250{ }^{\circ} \mathrm{C}$ temperatures. The peak areas and triglycerides composition were calculated for each sample by retention time using Varian Chem Station software. The standards of triglyceride methyl esters purchased from Sigma-Aldrich were also run under the same conditions for comparison with experimental samples.

\section{Physico-chemical and oxidative parameters}

The color ( $R$ value) of non-interesterified and interesterified samples was determined by Lovibond Tintometer using 5.25" quartzcell. Melting point of samples was assessed by AOAC [15] Method No. 920-157. The refractive index of blends was recorded by means of Abbe's refractometer at room temperature following the protocol No. Cc 7-25 as described in AOCS [14]. Specific gravity of samples was measured at $25{ }^{\circ} \mathrm{C}$ with specific gravity bottle (Pycnometer, Sigma-Aldrich) according to AOCS [14] Method No. Cc 10a-25. Saponification value (Method No. Cd 3-25), iodine value (Method No. Cd 1d-92), peroxide value (Method No. Cd 8-53) and free fatty acid value (Method No. Ca 5a-40) of CaO:FHCSO blends were estimated by following AOCS [14], respectively.

\section{Sensory evaluation}

Fourteen panel judges consisting of experienced and untrained panelists carried out the sensory analysis of samples according to the instructions given by Meilgaard et al. [16]. Each judge gave written informed consent after explanation of risks and benefits of participation prior to the study. The panelists were provided informative instructions and brief definitions of attributes such as appearances, flavor and overall acceptability. Each panelist received the samples assigned with random three-digit code numbers. Each panelist was asked to list their preference on a 9-cm comparison line $(1=$ dislike extremely to $9=$ like extremely). The sensory analysis was performed and completed at 0,30 and 60 days of storage interval for experimental treatments.

\section{Statistical analysis}

The data obtained for each parameter was subjected to statistical analysis to determine the level of significance by using the software package (Statistic 8.1 ) according to the method described [17]. The Duncan's multiple range (DMR) test was used to estimate the level of significance that existed between the mean values.

\section{Results and discussion}

Fatty acids composition and physico-chemical characteristics of raw materials

The raw materials, $\mathrm{CaO}$ and FHCSO, were analyzed for their fatty acids composition and physico-chemical parameters before $\mathrm{CaO}$ :FHCSO blend preparation. The oil contents in canola seed were found $40.5 \pm 2.8 \%$. The oleic $(58.3 \pm 0.6 \%)$, linoleic $(22.8 \pm 0.5 \%)$, $\alpha$-linolenic $(9.7 \pm$ $0.4 \%)$, palmitic $(4.5 \pm 0.3 \%)$ and stearic acids $(1.6 \pm 0.2 \%)$ were predominantly present in $\mathrm{CaO}$. Refined and bleached $\mathrm{CaO}$ showed Lovibond color $\mathrm{R}$ value $(1.48 \pm 0.14)$, melting point $\left(-9 \pm 1{ }^{\circ} \mathrm{C}\right)$, refractive index $(1.465 \pm 0.002)$, specific gravity $(0.921 \pm 0.001)$, saponification value $(188 \pm 3)$, iodine value $(122 \pm 3)$, peroxide value $(0.165 \pm 0.008 \mathrm{meq} / \mathrm{kg})$ and free fatty acids value $(0.1 \pm 0.004 \%)$. The contents of stearic acid $(72 \pm 0.8 \%)$ were found significantly higher in FHCSO obtained from local Vanaspati manufacturing industry followed by palmitic acid $(20 \pm 0.5 \%)$ and oleic acid $(4 \pm 0.3 \%)$. FHCSO possessed Lovibond color R value $(2.1 \pm 0.22)$, melting point $\left(59 \pm 1{ }^{\circ} \mathrm{C}\right)$, refractive index (1.472 \pm 0.003$)$, specific gravity $(0.918 \pm 0.001)$, saponification value $(198 \pm 2)$, iodine value $(6 \pm 2)$, peroxide value $(0.167 \pm 0.006 \mathrm{meq} / \mathrm{kg})$ and free fatty acids value $(0.098 \pm 0.003 \%)$.

\section{TAG composition of $\mathrm{CaO}$ :FHCSO blends}

The TAG profile is known as potential key for the understanding of several physico-chemical properties of given oil or fat developed through modification process. The major TAG classification (trisaturated $=S_{3}$; monounsaturated $=\mathrm{S}_{2} \mathrm{U}$; diunsaturated $=\mathrm{U}_{2} \mathrm{~S}$; triunsaturated $=\mathrm{U}_{3}$ ) of Cao:FHCSO blends before and after interesterification process at different storage days has been presented in Table 1. The results show that addition of FHCSO to $\mathrm{CaO}$ before interesterification increased the saturated fatty acids 
Table 1 Effect of interesterification process on triacylglycerol classes of canola oil and fully hydrogenated cottonseed oil blends

\begin{tabular}{|c|c|c|c|c|c|}
\hline \multirow[t]{3}{*}{ Triacylglycerol (TAG, \%) } & \multirow{3}{*}{$\begin{array}{l}\text { Experimental } \\
\text { treatment }\end{array}$} & \multicolumn{4}{|c|}{ Processing and storage time } \\
\hline & & \multirow[t]{2}{*}{ Before IE } & \multicolumn{3}{|l|}{ After IE } \\
\hline & & & 0 day & 30 days & 60 days \\
\hline \multirow[t]{3}{*}{ Trisaturated $\left(\mathrm{S}_{3}\right)$} & $\mathrm{T}_{1}$ & $18.6 \pm 0.2^{a}$ & $3.3 \pm 0.1^{b}$ & $4.3 \pm 0.1^{b}$ & $5.1 \pm 0.2^{b}$ \\
\hline & $\mathrm{T}_{2}$ & $42.4 \pm 0.4^{a}$ & $23.7 \pm 0.3^{b}$ & $24.3 \pm 0.3^{b}$ & $25.1 \pm 0.4^{b}$ \\
\hline & $\mathrm{T}_{3}$ & $63.9 \pm 0.5^{\mathrm{a}}$ & $39.6 \pm 0.4^{b}$ & $40.4 \pm 0.4^{b}$ & $41 \pm 0.3^{b}$ \\
\hline \multirow[t]{3}{*}{ Monounsaturated $\left(\mathrm{S}_{2} \mathrm{U}\right)$} & $\mathrm{T}_{1}$ & $1.1 \pm 0.1^{b}$ & $10.2 \pm 0.2^{\mathrm{a}}$ & $11.4 \pm 0.2^{a}$ & $12.5 \pm 0.2^{a}$ \\
\hline & $\mathrm{T}_{2}$ & $0.7 \pm 0.1^{b}$ & $17.8 \pm 0.2^{a}$ & $18.3 \pm 0.3^{a}$ & $19 \pm 0.3^{a}$ \\
\hline & $\mathrm{T}_{3}$ & $0.5 \pm 0.1^{b}$ & $21.4 \pm 0.3^{\mathrm{a}}$ & $21.8 \pm 0.2^{a}$ & $22.2 \pm 0.3^{a}$ \\
\hline \multirow[t]{3}{*}{ Diunsaturated $\left(\mathrm{U}_{2} \mathrm{~S}\right)$} & $\mathrm{T}_{1}$ & $16.8 \pm 0.2^{b}$ & $50.4 \pm 0.5^{\mathrm{a}}$ & $49.2 \pm 0.4^{\mathrm{a}}$ & $48.3 \pm 0.4^{\mathrm{a}}$ \\
\hline & $\mathrm{T}_{2}$ & $9.4 \pm 0.2^{b}$ & $29.5 \pm 0.3^{\mathrm{a}}$ & $29.1 \pm 0.3^{\mathrm{a}}$ & $28 \pm 0.4^{a}$ \\
\hline & $\mathrm{T}_{3}$ & $5.5 \pm 0.1^{b}$ & $19.6 \pm 0.2^{a}$ & $19 \pm 0.2^{\mathrm{a}}$ & $18.3 \pm 0.3^{a}$ \\
\hline \multirow[t]{3}{*}{ Triunsaturated $\left(\cup_{3}\right)$} & $\mathrm{T}_{1}$ & $63.1 \pm 0.6^{\mathrm{a}}$ & $32.9 \pm 0.3^{b}$ & $30.4 \pm 0.4^{c}$ & $28.6 \pm 0.3^{d}$ \\
\hline & $\mathrm{T}_{2}$ & $46.7 \pm 0.4^{\mathrm{a}}$ & $25.4 \pm 0.3^{b}$ & $24.2 \pm 0.4^{c}$ & $23.5 \pm 0.3^{d}$ \\
\hline & $\mathrm{T}_{3}$ & $29.5 \pm 0.3^{\mathrm{a}}$ & $15.9 \pm 0.2^{b}$ & $15.5 \pm 0.2^{c}$ & $15 \pm 0.2^{d}$ \\
\hline \multirow[t]{3}{*}{ Total Saturated (S) } & $\mathrm{T}_{1}$ & $18.6 \pm 0.2^{a}$ & $3.3 \pm 0.1^{b}$ & $4.3 \pm 0.1^{b}$ & $5.1 \pm 0.2^{b}$ \\
\hline & $\mathrm{T}_{2}$ & $42.4 \pm 0.4^{\mathrm{a}}$ & $23.7 \pm 0.3^{b}$ & $24.3 \pm 0.3^{b}$ & $25.1 \pm 0.4^{b}$ \\
\hline & $\mathrm{T}_{3}$ & $63.9 \pm 0.5^{\mathrm{a}}$ & $39.6 \pm 0.4^{b}$ & $40.4 \pm 0.4^{b}$ & $41 \pm 0.3^{b}$ \\
\hline \multirow[t]{3}{*}{ Total Unsaturated $(U)$} & $\mathrm{T}_{1}$ & $81 \pm 0.6^{d}$ & $93.5 \pm 0.7^{\mathrm{a}}$ & $91 \pm 0.8^{b}$ & $89.4 \pm 0.7^{c}$ \\
\hline & $\mathrm{T}_{2}$ & $56.8 \pm 0.6^{d}$ & $72.7 \pm 0.6^{a}$ & $71.6 \pm 0.8^{b}$ & $70.5 \pm 0.7^{c}$ \\
\hline & $\mathrm{T}_{3}$ & $35.5 \pm 0.4^{d}$ & $56.9 \pm 0.5^{a}$ & $56.2 \pm 0.5^{b}$ & $55 \pm 0.6^{c}$ \\
\hline \multirow[t]{3}{*}{ U/S ratio } & $\mathrm{T}_{1}$ & $4.35 \pm 0.2^{d}$ & $28.3 \pm 0.3^{\mathrm{a}}$ & $21.1 \pm 0.3^{b}$ & $17.5 \pm 0.2^{c}$ \\
\hline & $\mathrm{T}_{2}$ & $1.33 \pm 0.2^{d}$ & $3.06 \pm 0.2^{a}$ & $2.94 \pm 0.3^{b}$ & $2.80 \pm 0.3^{c}$ \\
\hline & $\mathrm{T}_{3}$ & $0.55 \pm 0.1^{d}$ & $1.43 \pm 0.1^{\mathrm{a}}$ & $1.36 \pm 0.2^{b}$ & $1.29 \pm 0.2^{c}$ \\
\hline \multirow[t]{3}{*}{ Total TAG } & $\mathrm{T}_{1}$ & $99.6 \pm 0.3^{a}$ & $96.8 \pm 0.6^{b}$ & $95.3 \pm 0.8^{b}$ & $94.5 \pm 0.8^{c}$ \\
\hline & $\mathrm{T}_{2}$ & $99.2 \pm 0.4^{a}$ & $96.4 \pm 0.5^{b}$ & $95.9 \pm 0.6^{b}$ & $95.6 \pm 0.7^{b}$ \\
\hline & $T_{3}$ & $99.4 \pm 0.4^{\mathrm{a}}$ & $96.5 \pm 0.7^{b}$ & $95.7 \pm 0.8^{b}$ & $95.3 \pm 0.9^{b}$ \\
\hline
\end{tabular}

IE: Interesterification; $\mathrm{T}_{1}$ (75 \% CaO:25 \% FHCSO); $\mathrm{T}_{2}$ (50\% CaO:50 \% FHCSO); $\mathrm{T}_{3}$ (25\% CaO:75 \% FHCSO); Total saturated (S) calculated by Saturated ( $\mathrm{S}_{3}$ ); Total Unsaturated $(\mathrm{U})$ calculated by Monounsaturated $\left(\mathrm{S}_{2} \mathrm{U}\right)$ + Diunsaturated $\left(\mathrm{U}_{2} \mathrm{~S}\right)$ + Triunsaturated $\left(\mathrm{U}_{3}\right)$; Values represent the mean \pm standard deviation; $n=3$

$a, b, c, d$ Means in a row with different superscripts were significantly different $(p<0.05)$

'Total TAG calculated by Saturated $\left(\mathrm{S}_{3}\right)+$ Monounsaturated $\left(\mathrm{S}_{2} \mathrm{U}\right)+$ Diunsaturated $\left(\mathrm{U}_{2} \mathrm{~S}\right)+$ Triunsaturated $\left(\mathrm{U}_{3}\right)$

contents in different blends. Maximum $\mathrm{S}_{3}$ contents $(63.9 \pm 0.5 \%)$ were found in $T_{3}$ while $S_{2} U, U_{2} S$ and $U_{3}$ contents were quite low in $\mathrm{T}_{2}$ and $\mathrm{T}_{3}$ when were directly compared with $T_{1}$ before interesterification of Cao:FHCSO blends. A marked reduction in $\mathrm{S}_{3}$ and $\mathrm{U}_{3}$ contents was observed for all experimental treatments on completion of interesterification. On the other hand, $\mathrm{S}_{2} \mathrm{U}$ and $U_{2} S$ contents of $T_{1}, T_{2}$ and $T_{3}$ increased significantly after interesterification. Maximum increment in $\mathrm{U}_{2} \mathrm{~S}$ contents was recorded for $T_{1}$ with highest value $(50.4 \pm 0.5 \%)$. There are many reports on effects of interesterification on TAG composition of the end product which evident that the concentrations of several TAG were increased, some were decreased, and several new TAG was formed [18]. The randomization process causes rearrangement of TAG species, reduction of $S_{3}$ and $U_{3}$ contents and increase in $\mathrm{S}_{2} \mathrm{U}$ and $\mathrm{U}_{2} \mathrm{~S}$ TAGs [19-25]. After interesterification, the high proportions of $S_{3}$ present in the starting blends were reduced $73-89 \%$ and greatest changes were observed for the blends with 40-50\% hard stock (a relative decrease of $\mathrm{U}_{3}$ of $38-64 \%$ and a relative increase of $\mathrm{U}_{2} \mathrm{~S}$ of $59-130 \%$ for different edible oil blends [26]. Total unsaturated (U)/ Total saturated $(S)$ ratio increased significantly from their initial value after interesterification with order $\mathrm{T}_{1}(28.3 \pm$ $0.3 \%)>\mathrm{T}_{2}(3.06 \pm 0.2 \%)>\mathrm{T}_{3}(1.43 \pm 0.1 \%)$. The U/S ratios for interesterified Cao:FHCSO blends were higher than 1 and conformed to the recommendation of the Food and Agricultural Organization/World Health Organzation (FAO/WHO) and European Union Committee (EUC) for a minimal unsaturated fatty acids/saturated fatty acids ratio [26]. During storage, the changes in $\mathrm{S}_{3}, \mathrm{~S}_{2} \mathrm{U}$ and $\mathrm{U}_{2} \mathrm{~S}$ contents were not found significant $(p \geq 0.05)$. However, maximum decrease 13, 7.5 and $5.6 \%$ in $U_{3}$ contents for $T_{1}, T_{2}$ and $\mathrm{T}_{3}$ was noted after 60-days of interesterification, respectively. Similarly, the unsaturated fatty acids/saturated fatty acids ratios of refined cottonseed oil and virgin olive 
oil blend samples after chemical interesterification showed slight reduction during 28 days storage at $60{ }^{\circ} \mathrm{C}$ [27]. The zero-trans margarine manufactured from various liquid oils blends using $0.5 \%$ sodium methoxide catalyst at $70{ }^{\circ} \mathrm{C}$ and vigorous agitation for $15 \mathrm{~min}$ appeared to remain preserved after interesterification [28]. The total TAG contents of all experimental treatments slightly decreased after interesterification and significantly during storage $(p \leq 0.05)$ which may indicate the production of partial mono- and diacylglycerols in Cao:FHCSO blends. Similar results were observed by Kowalski et al. [29]. The desirable increments in $\mathrm{S}_{2} \mathrm{U}$ and $\mathrm{U}_{2} \mathrm{~S}$ contents of $\mathrm{T}_{2}$ point toward its better TAG composition as compared to $\mathrm{T}_{1}$ and $\mathrm{T}_{3}$. Specific structured lipids developed through TAG modification by interesterification have received increasing attention for treatment of nutritional disorders through their absorption, metabolism and distribution pattern into biological tissues and this may provide useful information for the preparation for dietary supplements with specific functions [30, 31].

\section{Physico-chemical characteristics of CaO:FHCSO blends}

Lovibond color units, melting point, refractive index, specific gravity, saponification value and iodine value are usually used for the identification of physico-chemical characteristics the oils and their blends. Physico-chemical results of the study are reported in Fig. 1.

\section{Lovibond color $\mathrm{R}$ value}

A steady decrease in Lovibond color $\mathrm{R}$ units was observed in all treatments after interesterification (Fig. 1a). The maximum decrease in color units was recorded for $\mathrm{T}_{3}(1.2 \pm 0.4)$ as compared to its initial value (1.75 \pm $0.6)$. The intensity of the color was seen to be lighter in $\mathrm{T}_{1}$, probably because of its refined state and was seen to have lowest color value of $1.1 \pm 0.3$ units. It was observed that color value of CaO:FHCSO blends increased non-significantly throughout the storage period $(p \geq 0.05)$. Slight changes and darkening in color may be attributed to several factors such as $\mathrm{S}_{3}$ composition of blend, tocopherol contents, storage conditions and oxidative effects during storage [32, 33]. Chemical interesterification significantly decreased the tocopherol contents of vegetable oil samples [27]. Tocopherol loss is the most important and probably the only known disadvantage of chemical interesterification as $\alpha$-Tocopherol has the highest vitamin $\mathrm{E}$ activity in vegetable oil blends. However, reducing the tocopherol content during interesterification does not inversely affect the oxidative stability of interesterified blends and tocopherol supplementation of interesterified oils with equal amounts of eliminated tocopherols can be successfully applied by related food industries [34].

\section{Melting point}

Melting point of a fat has direct relationship with its degree of hardness and it can be used as criterion of purity. Fig. 1b shows the melting profile of CaO:FHCSO blends before and after interesterification. The melting profile of blends was directly proportional to the $\mathrm{S}_{3}$ contents coming from the FHCSO before interesterification. However, after interesterification, a sudden decrease in melting profile for all blends was noted. Maximum decrease in melting profile $\left(7.3^{\circ} \mathrm{C}\right)$ was for $\mathrm{T}_{1}$ which may be associated with extensive rearrangement of fatty acids among TAG and proportionally decrease of $\mathrm{S}_{3}$ contents in the CaO:FHCSO blend. A blend of $70 \%$ hydrogenated canola oil, $10 \%$ palm stearin, and $20 \%$ canola oil had an initial dropping point of $37^{\circ} \mathrm{C}$, which dropped to $35{ }^{\circ} \mathrm{C}$ following $5 \mathrm{~min}$ of interesterification reaction and to $32{ }^{\circ} \mathrm{C}$ after $20 \mathrm{~min}$, remaining constant thereafter [35]. Scientific studies confirmed that hardfat contents of a given sample are directly related to high-meltingpoint components of processing blends [23, 25, 36]. After interesterification, an absolute decrease in the melting point, ranging from $7-31{ }^{\circ} \mathrm{C}$ was detected for the different vegetable oil blends which can be explained by the decrease of the higher-melting $S_{3}$ proportion [26]. The melting thermogram also confirmed the presence of interesterified product with lower melting point may be due the disappearance of the high melting TAGs [19, 24]. Furthermore, interesterification of fat blends with large amounts of hard stock (75 \%) produced little change in the melting point [21, 22, 26] which also confirmed the results reported in the present study. During preservation period, a slight increase in melting profile of all treatments was recorded which may be linked to partial conversion of $\mathrm{U}_{3}$ to $\mathrm{U}_{2} \mathrm{~S}, \mathrm{~S}_{2} \mathrm{U}$ and $\mathrm{S}_{3}$ through oxidative rancidity. It seems true that TAG type is the main determining factor for the attainment of blends with differentiated melting properties [36]. The research studies conclude that chemical interesterification of edible oil blends reduced melting points which are desirable physicochemical properties for possible use as margarine, shortenings and confectionary fats [37, 38].

\section{Refractive index and specific gravity}

The refractive index is a measure of extent of bending of light through a substance. The refractive index decreased slightly in all treatments with increasing conversion of $\mathrm{S}_{3}$ to $\mathrm{S}_{2} \mathrm{U}$ and $\mathrm{U}_{2} \mathrm{~S}$ components after interesterification. Refractive index was affected by the chain length and number of double bonds molecules present in CaO:FHCSO blend. However, data on refractive index during storage reflected the stability of the oil blends up to 2 months and it ranged from 1.463 to 1.67 units (Fig. 1c). Increase in free acid contents, peroxide values and high 

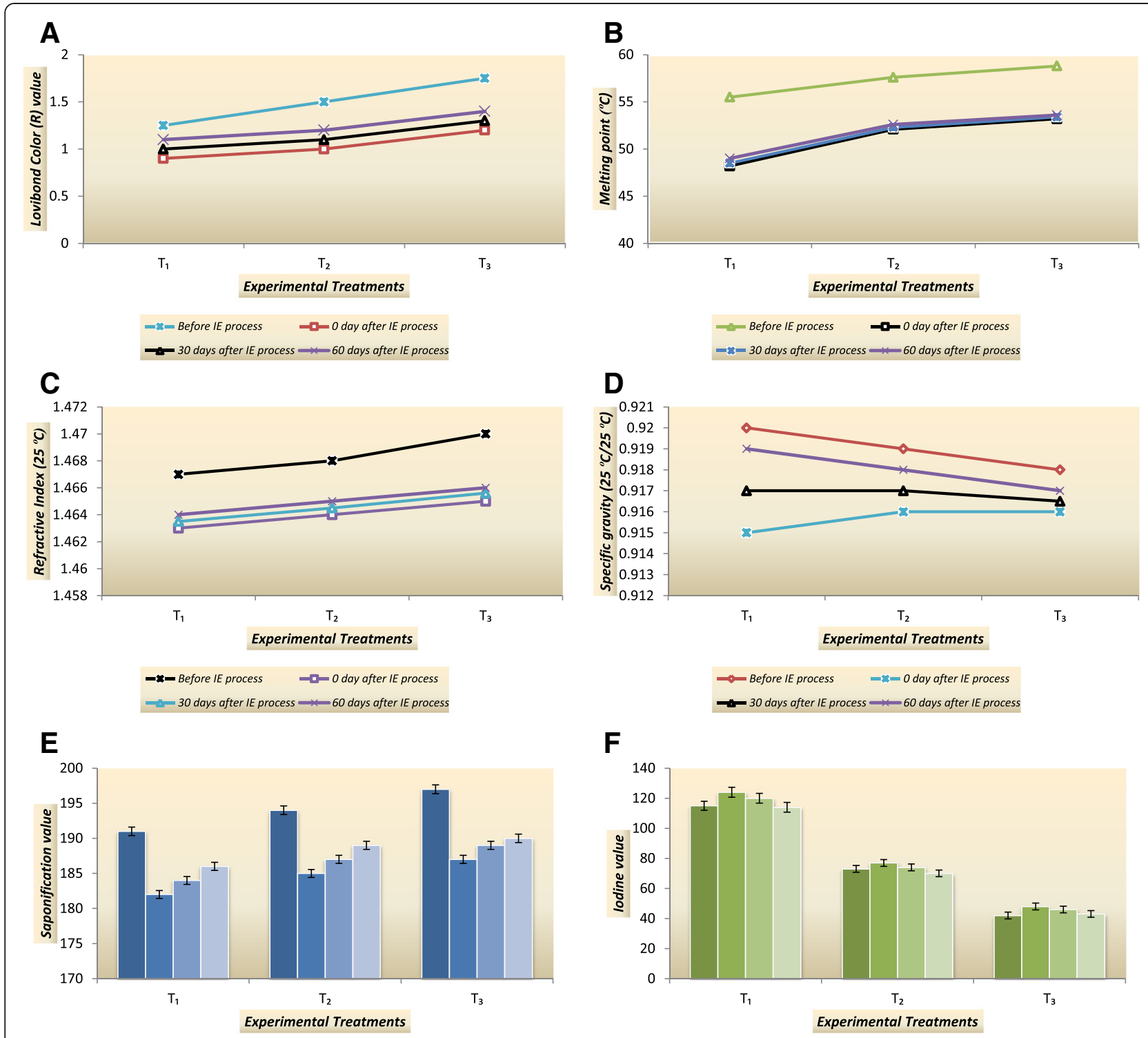

- Before IE process $\| 0$ day after IE process $\| 30$ days after IE process $\| 60$ days after IE process

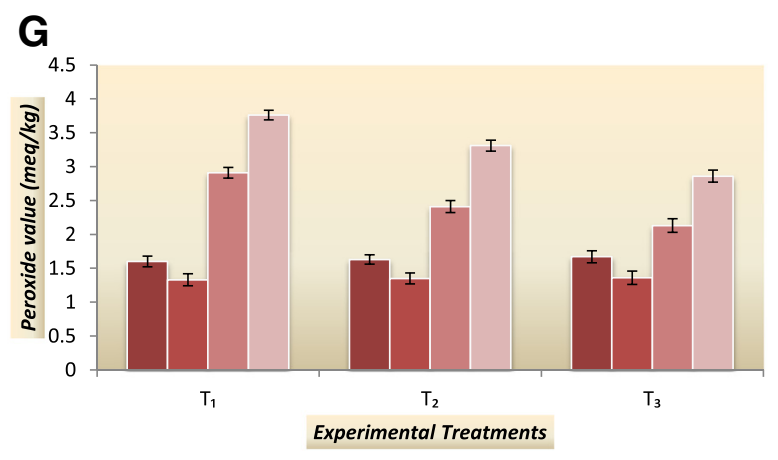

H

- Before IE process $\approx 0$ day after IE process $\backsim 30$ days after IE process $₫ 60$ days after IE process

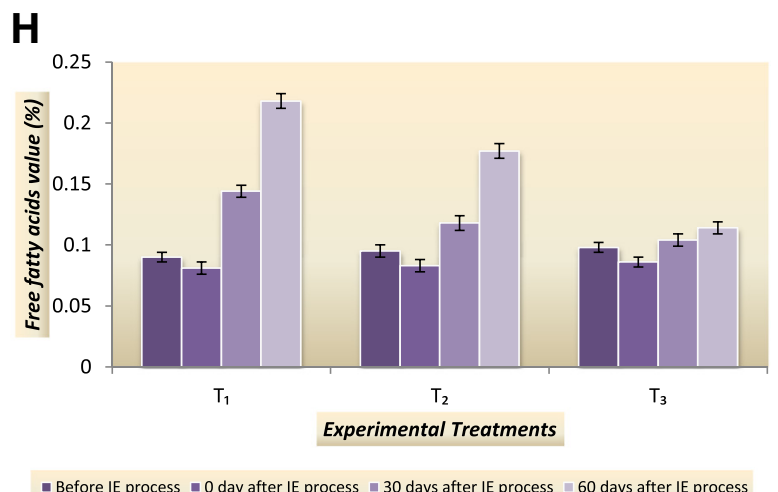

- Before IE process 0 day after IE process $=30$ days after IE process $=60$ days after IE process

- Before IE process $\| 0$ day after IE process $\approx 30$ days after IE process $\approx 60$ days after IE process

Fig. 1 Effect of chemical interesterification process on physico-chemical characteristics and oxidative stability of CaO:FHCSO blends (a Lovibond color $\mathrm{R}$ value, $\mathbf{b}$ melting point, $\mathbf{c}$ refractive index, $\mathbf{d}$ specific gravity, $\mathbf{e}$ saponification value, $\mathbf{f}$ iodine value, $\mathbf{g}$ peroxide value and $\mathbf{h}$ free fatty acids value) 
storage temperature have been documented as responsible factors for slight increase in refractive index units of vegetable oil blends during storage [39, 40]. The changes in specific gravity of $\mathrm{CaO}$ :FHCSO blends before and after interesterification were monitored regularly and are presented in Fig. 1d. Slight decrease in specific gravity was recorded for all treatments after interesterification which is likely due to more double bonds nature of Cao:FHCSO blends. During storage, these values were found with slight increasing trend which may be attributed to the formation of $S_{3}$ polymeric fractions.

\section{Saponification and iodine value}

Slight decrease in saponification values could be noticed after the completion of interesterification process indicating the development of proportionally more $\mathrm{U}_{2} \mathrm{~S}$ fractions in all treatments (Fig. 1e). $\mathrm{T}_{1}$ possessed lowest saponification value $(182 \pm 0.56)$ followed by $\mathrm{T}_{2}(185 \pm$ $0.57)$ and $T_{3}(187 \pm 0.58)$ which can be relate to presence of highest unsaturated contents in $\mathrm{T}_{1}(93.5 \pm 0.7), \mathrm{T}_{2}$ $(72.7 \pm 0.6)$ and $T_{3}(56.9 \pm 0.5)$, respectively (Table 1$)$. Saponification value is well-known index of the mean molecular weight of fatty acids comprising the triglycerides. The results indicate that triglyceride comprising of low molecular weight (short chain) fatty acids were more in $\mathrm{T}_{3}$ as compared to $\mathrm{T}_{2}$ and $\mathrm{T}_{3}$; therefore $\mathrm{T}_{3}$ showed high level of saponification value. The results further substantiated that saponification values were increased during storage for all treatments. For each CaO:FHCSO blend, increase in saponification value (1-2\%) was found after 60 days during storage period. Iodine value is considered as an index of the unsaturation, which is one of the most important analytical characteristic of oil. Data on changes in the iodine values of $\mathrm{CaO}$ :FHCSO blends are presented in Fig. 1f. The transition in iodine values was function of experimental $\mathrm{CaO}$ :FHCSO blends with concomitant decrease in unsaturated contents during blend formation while no change in degree of unsaturation was found after interesterification. It was also observed that iodine values decreased gradually during storage in the oil blends studied which may be due to decrease in double bonds by oxidative rancidity. Slow decrease in iodine value of oil blends may be due to induction period where fat was oxidized slowly showing initiation stage of auto oxidation reaction [33]. Rapid changes in iodine values of oil blends may be attributed to propagation of auto oxidation process where hydro peroxides are formed from free radicals in fatty acids generated in initiation stage or auto oxidation reaction. During the end of storage period slight change in iodine value was observed which might be due to termination stage of reaction [41].

\section{Oxidative stability of $\mathrm{CaO}: \mathrm{FHCSO}$ blends}

Lipids are composed of unsaturated and saturated fatty acids. The unsaturated parts are susceptible to oxidation when exposed to processing and storage and ultimately develop peroxide, hydro-peroxides, aldehydes, ketones, short chain fatty acids and finally bad smell. Oxidative changes in $\mathrm{CaO}$ :FHCSO blends were measured by peroxide and free fatty acid values which are displayed in Fig. 1.

\section{Peroxide value}

Peroxide value can be used to determine the degree of deterioration and amount of oxidative rancidity of original oils blends. The changes in the peroxide values of selected $\mathrm{CaO}: \mathrm{FHCSO}$ blends before interesterification, after interesterification and during storage can be seen in Fig. 1g. Peroxide values of $\mathrm{T}_{1}, \mathrm{~T}_{2}$ and $\mathrm{T}_{3}$ were not significantly different from each other before interesterification $(p \geq 0.05)$. The interesterified oils showed lower peroxide values than their non-interesterified counterparts in all CaO:FHCSO blends. Peroxide values of oil samples considerably increased up to $20 \mathrm{~min}$ of chemical interesterification, followed by a reduction at $30 \mathrm{~min}$ [27]. The reduction in peroxide values of vegetable oils after interesterification was also recorded by Basturk et al. [34] and Farmani et al. [42]. In the meanwhile, changes in peroxide values decreased as the concentration of FHCSO increased in the CaO:FHCSO blend during storage. $\mathrm{T}_{2}(3.31 \pm 0.08 \mathrm{meq} / \mathrm{kg})$ and $\mathrm{T}_{3}(2.86 \pm$ $0.09 \mathrm{meq} / \mathrm{kg}$ ) were seen well in oxidative stability than $\mathrm{T}_{1}(3.76 \pm 0.07 \mathrm{meq} / \mathrm{kg})$. However, the peroxide values of all $\mathrm{CaO}: F H C S O$ blends were recorded to be within the normal limits $(5 \mathrm{meq} / \mathrm{kg})$.

\section{Free fatty acids value}

Free fatty acids occur in fats as a result of enzymatic hydrolysis by lipases, metal ions acting as free radicals or at an elevation of temperature. The free fatty acid values expressed in percent oleic acid of experimental treatments is depicted in Fig. 1h. Free fatty acids readily undergo oxidation, so their raised amount causes color and flavor deterioration of product. Free fatty acids of all the $\mathrm{CaO}: \mathrm{FHCSO}$ blends were decreased after interesterification reaction. The decline in free fatty acids was may be due to the alkaline nature of sodium methylate used as catalyst. Sodium methylate is regarded as strong alkali and almost $70 \%$ of the catalyst is used in neutralization of free fatty acids, only $30 \%$ initiates and maintain the rearrangement reaction [43]. Free fatty acids in palm oil and palm olein blends were found quite low after chemical interesterification may be due to the reaction of alkaline sodium methylate catalyst with free acids [44]. The formation of free fatty acids in $\mathrm{CaO}$ :FHCSO blends were found to increase with increase in time of storage. $\mathrm{T}_{1}$ showed higher increasing trend for free fatty acids production as 


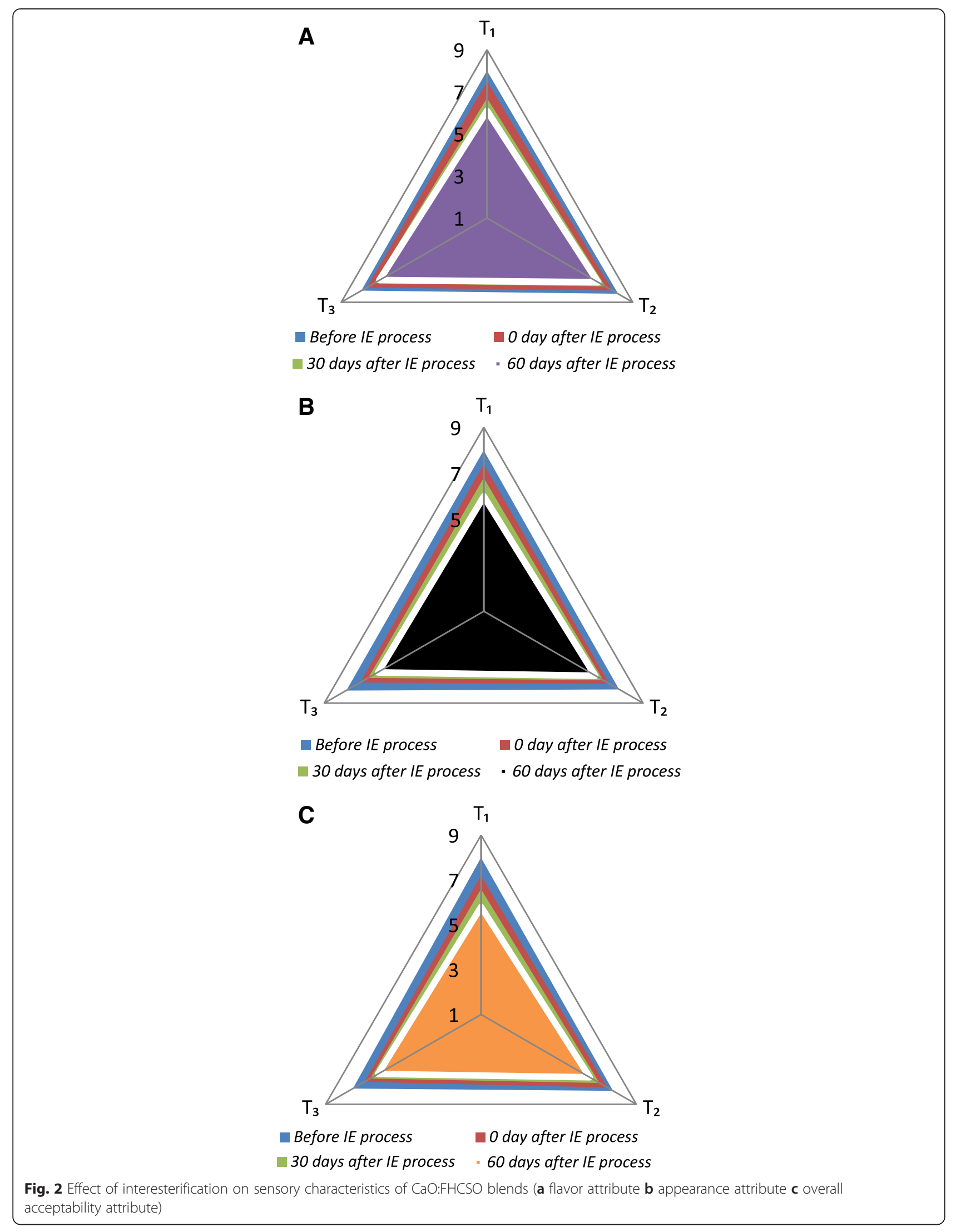


compared to $T_{2}$ and $T_{3}$ which can be explained on the basis of unsaturated TAG contents. Many authors have shown, however, that chemical interesterification can negatively influence the oxidative stability of fats and oils during storage. Non-interesterified and interesterified oils (canola, linseed, soybean, and sunflower) stored at $55{ }^{\circ} \mathrm{C}$ demonstrated little difference to lipid oxidation, whereas samples were found more stable at $28{ }^{\circ} \mathrm{C}$ [45]. Oxidative storage stability is strongly affected by lipid type and the lipids used for production [30]. The presence of non-TAG fraction in the interesterification products also lowers their resistance to oxidation [46] which seems true in present study as all experimental blends possessed less total TAGs at the end of storage period whereas the starting mixture showed the highest TAGs fraction. The optimum combination of hydrogenation and random interesterification can improve the oxidative stability of raw oils to expand the application in foods [47]. Moreover, the oxidative stability of the interesterified fats, which is reduced during storage, can be significantly improved using antioxidants [24]. Great importance is attributed to the bioactive components such as vitamin $\mathrm{E}$ and carotenoids to enhance the oxidative stability in food and biological system. However, the changes in findings may arise from the use of synthetic molecules slightly different from natural ones [48]. The supplementation of antioxidants in functional diet can protect human body from adverse events and dysfunction of metabolic syndrome because of the beneficial effects of these phytochemicals [49].

\section{Sensory evaluation of CaO:FHCSO blends}

Figure 2 represents the organoleptic ratings of $\mathrm{CaO}: \mathrm{FHCSO}$ blends under different storage intervals. Original $\mathrm{CaO}$ :FHCSO blends before interesterification obtained most desired scores for flavor, appearance and overall acceptability attributes. On interesterification, $\mathrm{CaO}$ :FHCSO blends maintained their sensory acceptability and very slight variations in sensory scores were noted as compared to initial values. The results of sensory analysis showed the acceptability of a zero-trans fat shortening prepared by chemical interesterification of vegetable oil blends [50]. Refined olive oil and palm oil blends of varying proportions subjected to interesterification produced plastic fats similar in sensory properties to soft and package type margarine [51]. All sensory attributes were observed to decrease significantly as storage length increased from day 30 to 60-days. However, $\mathrm{T}_{2}$ and $\mathrm{T}_{3}$ obtained more sensory acceptability as compared to $\mathrm{T}_{1}$ during the whole storage period. Similarly, intensity of flavor was found to decrease following chemically interesterification of $100 \%$ butterfat and $80 \%-20 \%$ butterfat-canola oil blends [52]. The trend of $\mathrm{T}_{2}$ and $\mathrm{T}_{3}$ desirability by sensory panel could be attributed to the composition and nature of fatty acids present in these $\mathrm{CaO}$ :FHCSO blends. The least desired sensory scores for $\mathrm{T}_{1}$ may be due to the higher amount of unsaturated contents present in CaO:FHCSO blend. In addition, oxidation of $\mathrm{CaO}: \mathrm{FHCSO}$ blends during storage were observed to correlate negatively with the acceptability of functional fats. The lowest sensory values for $T_{1}$ could also be linked to presence of aldehyde and ketone compounds which impacted the fishy like flavor in $\mathrm{CaO}$ :FHCSO blend at the end of study trial (after 60days). Randomization was found to have no detrimental effect on the sensory acceptability [24]. It is also well known that the presence of $\mathrm{U}_{2} \mathrm{~S}$ polymeric fractions with melting point in the range of $25{ }^{\circ} \mathrm{C}$ to $45^{\circ} \mathrm{C}$ in developed functional fats is responsible for sensory properties of products at room storage temperature [53]. Most important was the $50 \% \mathrm{CaO}: 50 \%$ FHCSO blend $\left(\mathrm{T}_{2}\right)$ which possessed the desirable TAG profile, physico-chemical and sensory characteristics coming from $\mathrm{T}_{1}$ and $\mathrm{T}_{3}$.

\section{Conclusions}

The results of present study conclude that the marked reduction in trisaturated and triunsaturated contents with concomitant increase in desirable monounsaturated and diunsaturated contents can be achieved successfully for all $\mathrm{CaO}$ :FHCSO blends on interesterification. Results from this work will aid in the formulation of more healthy fat and oil products and may address a critical industrial demand in terms of formulation options for spreads, margarines and shortenings. Efforts should be continue for the production of functional lipids using medium-chain acids and long-chain polyunsaturated fatty acids present in locally available sources through exploring interesterification process as forefront lipid modification technology. Additional studies should be undertaken to determine the maximal shelf life of products supplemented with interesterified $\mathrm{CaO}$ :FHCSO blends and treatment of nutritional disorders through their absorption, metabolism and distribution pattern into biological tissues.

\section{Competing interests \\ The authors declare that they have no competing interests.}

\section{Authors' contributions}

$\mathrm{MI}$ conceptualized and performed the study; MN provided the technical assistance and drafting the manuscript. Both authors read and approved the final manuscript.

\section{Acknowledgement}

Authors thanks the Library Department, Government College University Faisalabad (GCUF) and IT Department, Higher Education Commission (HEC) for access to journals, books and valuable database. The authors are highly obliged to the National Institute of Food Science and Technology, University of Agriculture, Faisalabad and United Industries, Ltd. Faisalabad, Pakistan for use of laboratory equipment and supplies to complete this research work.

\section{Author details}

${ }^{1}$ Institute of Home and Food Sciences, Faculty of Science and Technology, Government College University, Faisalabad, Pakistan. ${ }^{2}$ Department of Dairy Technology, University of Veterinary and Animal Sciences, Lahore, Pakistan. 
Received: 25 July 2015 Accepted: 21 October 2015

\section{Published online: 29 October 2015}

\section{References}

1. Calder PC. Functional roles of fatty acids and their effects on human health. JPEN J Parenter Enteral Nutr. 2015;39(1 Suppl):18S-32S.

2. Marcus JB. Culinary nutrition: the science and practice of healthy cooking. USA: Academic; 2013. p. 660.

3. Smith KW. Structured triacylglycerols: Properties and processing for use in food. In: Talbot G, editor. Specialty oils and fats in food and nutrition properties. Processing and applications. A volume in Woodhead publishing series in food science. USA: Technology and Nutrition; 2015. p. 207-18.

4. Haumann BF. Fat modification tools: hydrogenation, interesterification. Inform. 1994;5:668-78.

5. Kadhum AAH, Shamma MN. Edible lipids modification processes: A review. Crit Rev Food Sci Nutr. 2015. doi:10.1080/10408398.2013.848834.

6. Monganga WS. Effect of non hydrogenated cottonseed oil on the flavor quality and stability of high oleic low linolenic canola oil during potato chip processing. Ann Arbor, Michigan, USA: ProQuest LLC Publishers; 2009. p. 2-3.

7. Dhaka V, Gulia N, Ahlawat KS, Khatkar BS. Trans fats-sources, health risks and alternative approach - A review. J Food Sci Technol. 2011;48:534-41.

8. Napolitano G, Giuffrida F. Replacement of partially hydrogenated oils in food products: a technological challenge. In: Destaillats F, Sébédio J-L, Dionisi F, Chardigny J-M, editors. Trans fatty acids in human nutrition. 2nd ed. USA: A volume in Oily Press Lipid Library Series; 2012. p. 147-62.

9. Arellano M, Norton IT, Smith P. Specialty oils and fats in margarines and low-fat spreads. In: Talbot G, editor. Specialty oils and fats in food and nutrition properties. Processing and applications. A volume in Woodhead publishing series in food science. USA: Technology and Nutrition; 2015. p. 241-70.

10. Menaa F, Menaa A, Tréton J, Menaa B. Technological approaches to minimize industrial trans fatty acids in foods. J Food Sci. 2013;78:377-86.

11. Dinç S, Javidipour I, Ozbas OÖ, Tekin A. Utilization of zero-trans non-interesterified and interesterified shortenings in cookie production. J Food Sci Technol. 2014;51:365-70.

12. Fauzi SH, Rashid NA, Omar Z. Effects of chemical interesterification on the physicochemical, microstructural and thermal properties of palm stearin, palm kernel oil and soybean oil blends. Food Chem. 2013;137:8-17.

13. Grimaldi R, Gonçalves LAG, Ando MY. Otimização da reação de interesterificação química de óleo de palma. Quim Nova. 2005;28:633-6.

14. AOCS. Official methods and recommended practices of AOCS. 5th ed. Champaign, IL, USA: American Oil Chemists Society; 1998.

15. AOAC. Official methods of analysis. 15th ed. Washington, DC, USA: The Association of the Official Analytical Chemists; 1990.

16. Meilgaard MC, Civille GV, Carr BT. Sensory evaluation techniques. 4th ed. Boca Raton, Florida, USA: CRC Press; 2007. p. 464.

17. Steel RGD, Torrie JH, Dickey D. Principles and procedures of statistics, a biometrical approach. 3rd ed. New York: McGraw Hill Book Co Inc, USA; 1997.

18. Noor Lida HMD, Sundram K, Siew WL, Aminah A, Mamot S. TAG composition and solid fat content of palm oil, sunflower oil, and palm kernel olein belends before and after chemical interesterification J Am Oil Chemists' Soc. 2002;79:1137-44.

19. Norizzah AR, Chong CL, Cheow CS, Zaliha O. Effects of chemical interesterification on physicochemical properties of palm stearin and palm kernel olein blends. Food Chem. 2004;86:229-35.

20. Ahmadi L, Wright AJ, Marangoni AG. Chemical and enzymatic interesterification of tristearin/ triolein-rich blends: Chemical composition, solid fat content and thermal properties. European J Lipid Sci Tech. 2008;110:1014-24.

21. Ribeiro APB, Basso RC, Grimaldi R, Gioielli LA, Gonçalves LAG. Effect of chemical interesterification on physicochemical properties and industrial applications of canola oil and fully hydrogenated cottonseed oil blends. J Food Lipids. 2009;16:362-81.

22. Ribeiro APB, Grimaldi $R$, Gioielli LA, Gonçalves LAG. Zero trans fats from soybean oil and fully hydrogenated soybean oil: Physico-chemical properties and food applications. Food Res Int. 2009;42:401-10.

23. Da Silva RC, Soares DF, Lourenco MB, Soares FASM, da Silva KG, Goncalves MIA, et al. Structured lipids obtained by chemical interesterification of olive oil and palm stearin. LWT-Food Sci Tech. 2010;43:752-8.
24. Liu Y, Meng Z, Shan L, Jin Q, Wang X. Preparation of specialty fats from beef tallow and canola oil by chemical interesterification: physico-chemical properties and bread applications of the products. European Food Res Tech. 2010;230:457-66.

25. Jenab E, Temelli F, Curtis JM. Lipase-catalysed interesterification between canola oil and fully hydrogenated canola oil in contact with supercritical carbon dioxide. Food Chem. 2013;141:2220-8.

26. Petrauskaite V, Greyt WD, Kellens M, Huyghebaert A. Physical and chemical properties of trans -free fats produced by chemical interesterification of vegetable oil blends. J Am Oil Chemists' Soc. 1998;75:489-93.

27. Javidipour I, Tüfenk R, Baştürk A. Effect of ascorbyl palmitate on oxidative stability of chemically interesterified cottonseed and olive oils. J Food Sci Technol. 2015;52:876-84.

28. List GR, Mounts TL, Orthoefer F, Neff WE. Margarine and shortening oils by interesterification of liquid and trisaturated triglycerides. J Am Oil Chemists' Soc. 1995;72:379-82.

29. Kowalski B, Tarnowska K, Gruczynska E, Bekas W. Chemical and enzymatic interesterification of a beef tallow and rapeseed oil equal-weight blend. European J Lipid Sci Tech. 2004;106:655-64.

30. Timm-Heinrich M, Nielsen NS, Xu X, Jacobsen C. Oxidative stability of structured lipids containing C18:0, C18:1, C18:2, C18:3 or CLA in sn2-position as bulk lipids and in milk drinks. Innovat Food Sci Emerg Tech. 2004;5:249-61.

31. Berry SE. Triacylglycerol structure and interesterification of palmitic and stearic acid-rich fats: an overview and implications for cardiovascular disease. Nutr Res Rev. 2009;22:3-17.

32. Sundararaj $P$, Siddhu A, Valsalan A. Storage and frying stability of rice bran oil. SAARC Oils and Fats Today. 2002;52:9-14

33. Gulla S, Waghray K. Effect of storage on physico-chemical characteristics and fatty acid composition of selected oil blends. J Life Sci. 2011;3:35-46.

34. Basturk A, Javidipour I, Boyacı $\mathbb{H}$. Oxidative stability of natural and chemically interesterified cottonseed, palm and soybean oils. J Food Lipids. 2007;14:170-88.

35. Cho F, Deman JM, Allen OB. Application of simple-centroid design for the formulation of partially interesterified canola/palm blends. J Food Lipids. 1993;1:25-52.

36. Humphrey KL, Narine SS. A comparison of lipid shortening functionality as a function of molecular ensemble and shear: Crystallization and melting. Food Res Int. 2004;37:11-27.

37. Karabulut I, Turan S, Ergin G. Effects of chemical interesterification on solid fat content and slip melting point of fat/oil blends. European Food Res Tech. 2004;218:224-9.

38. Soares FA, da Silva RC, Hazzan M, Capacla IR, Viccola ER, Maruyama JM, et al. Chemical interesterification of blends of palm stearin, coconut oil, and canola oil: physicochemical properties. J Agric Food Chem. 2012;60:1461-9.

39. Padmavathy A, Siddhu A, Sundararaj P. Effect of blending edible grade crude palm oil with refined groundnut or sunflower oils on storage stability and sensory attributes. J Oil Techn Assoc India. 2001;33:93-103.

40. Semwal AD, Arya SS. Studies on the stability of some edible oils and their blends during storage. J Food Sci Technol. 2001;38:515-8.

41. Nasirullah KN, Ankaiah MN, Krishnamurthy MN, Nagaraja KV. Quality characteristics of edible vegetable oil blends. J Am Oil Chemists' Soc. 1991;68:446-7

42. Farmani J, Safari M, Hamedi M. Trans-free fats through interesterification of canola oil/palm olein or fully hydrogenated soybean oil blends. European J Lipid Sci Tech. 2009;111:1212-20.

43. Erickson DR. Practical hand book of soybean processing and utilization NY, USA: Mc. Graw Hill Publishing Company; 1995. p. 584.

44. Farmani J, Safari M, Hamedi M. Application of palm olein in the production of zero-trans Iranian vanaspati through enzymatic interesterification. European J Lipid Sci Tech. 2006;108:636-43.

45. Tautorus $\mathrm{CL}, \mathrm{McC}$ rdy AR. Effect of randomization on oxidative stability of vegetable oils at two different temperatures. J Am Oil Chemists' Soc. 1990;67:525-30.

46. Ledóchowska E, Wilczyńska E. Comparison of the oxidative stability of chemically and enzymatically interesterified fats. European J Lipid Sci Tech. 1998;100:343-8

47. Daniels RL, Kim HJ, Min DB. Hydrogenation and interesterification effects on the oxidative stability and melting point of soybean oil. J Agric Food Chem. 2006;54:6011-5 
48. Ciccone MM, Cortese F, Gesualdo M, Carbonara S, Zito A, Ricci G, et al, Dietary intake of carotenoids and their antioxidant and anti-inflammatory effects in cardiovascular care. Mediators Inflamm. 2013;782137:1-11.

49. Scicchitano P, Cameli M, Maiello M, Modesti PA, Muiesan ML, Novo S, et al. Nutraceuticals and dyslipidaemia: Beyond the common therapeutics. J Funct Foods. 2014;6:11-32.

50. Ahmadi L, Marangoni AG. Functionality and physical properties of interesterified high oleic shortening structured with stearic acid. Food Chem. 2009;117:668-73.

51. Alpaslan M, Karaali A. The interesterification-induced changes in olive and palm oil blends. Food Chem. 1998;61:301-5.

52. Rousseau D, Marangoni AG. The effects of interesterification on physical and sensory attributes of butterfat and butterfat-canola oil spreads. Food Res Int. 1998;31:381-8.

53. Rodrigues JN, Gioielli LA, Anton C. Propriedades físicas de lipídios estruturados obtidos de misturas de gordura do leite e óleo de milho. Cienc Tecnol Aliment. 2003;23:226-33.

\section{Submit your next manuscript to BioMed Central and take full advantage of:}

- Convenient online submission

- Thorough peer review

- No space constraints or color figure charges

- Immediate publication on acceptance

- Inclusion in PubMed, CAS, Scopus and Google Scholar

- Research which is freely available for redistribution 